\title{
Eastern Orthodox Christian
}

National Cancer Institute

\section{Source}

National Cancer Institute. Eastern Orthodox Christian. NCI Thesaurus. Code C103288.

A religious group whose beliefs are based on the practices defined by the first seven

ecumenical councils and whose members are located in or descended from the people of Eastern or Southeastern Europe. 